\title{
Vitamin D deficiency in patients with acute coronary syndrome
}

\author{
Elena Shytova, Larisa Mikhailova, Robert Bogachev, Anastasia Kozel, Vitaly Ankudovich, Ulyana Dobrynina \\ Immanuel Kant Baltic Federal University, University of Medicine, Kaliningrad, Russian Federation
}

Background: Recent studies have shown that the functions of vitamin $D$ are abundant, including its impact on the development of coronary artery disease (CAD).

Aims: Assess the serum vitamin D level in patients with acute coronary syndrome and compare with a group of healthy volunteers. Subjects and methods: It is a cross-sectional observational study. Study subjects are patients with acute coronary syndrome. Exclusion criteria are the presence of diabetes mellitus, autoimmune diseases and malignant tumors. The control group included subjects without any cardiac disorders. Between August 2017 and November 2017, 50 patients with ACS and 22 healthy volunteers were enrolled in our study. The mean age of the participants in the ACS cohort was $59.9 \pm 7.7$ years, with a predominance of males $(70 \%)$. Results: In the vast majority of patients with ACS, vitamin D deficiency was found. A marked deficiency was seen in $78 \%$. Vitamin D deficiency was not observed in the control group, but insufficiency was detected in $64 \%$. According to coronary angiography results, almost a half of the patients ( $45 \%$ ) with ACS and vitamin D deficiency had multivessel CAD.

Conclusions: We have found in our limited observation that the overwhelming majority of patients with acute coronary syndrome have vitamin D deficiency, in contrast to the control group - individuals with no cardiovascular problems.

Key words: vitamin D deficiency, acute coronary syndrome, coronary artery disease.

\section{Deficit vitaminu D u pacientů s akutním koronárním syndromem}

Úvod: Nedávné studie prokázaly, že funkcí vitaminu D je celá řada, a to včetně jeho vlivu na vznik ischemické choroby srdeční (ICHS). Cíl: Stanovit hladinu vitaminu D v séru u pacientů s akutním koronárním syndromem (AKS) a provést srovnání se skupinou zdravých dobrovolníků.

Materiál and metody: Jedná se o průřezovou observační studii. Studovanými subjekty jsou pacienti s akutním koronárním syndromem. Kritéria pro vyloučení ze studie jsou př́tomnost diabetes mellitus, autoimunitních onemocnění a zhoubných nádorů. Do kontrolní skupiny byli zařazeni jedinci bez jakýchkoli srdečních poruch.

Výsledky: U převážné většiny pacientů s AKS byl zjištěn deficit vitaminu D. Výrazný deficit byl objeven u $78 \%$. U kontrolní skupiny nebyl deficit vitaminu D pozorován, nicméně u 64 \% byla zjištěna insuficience. Na základě výsledků koronarografie téměř polovina pacientů (45\%) s AKS a deficitem vitaminu D měla ICHS s postižením více tepen.

Závěr: Z našeho skromného pozorování vyplývá, že naprostá většina pacientů s akutním koronárním syndromem má deficit vitaminu $D$, na rozdíl od kontrolní skupiny, tj. osob bez kardiovaskulárních problémů.

Klíčová slova: deficit vitaminu D, akutní koronární syndrom, ischemická choroba srdeční.

\section{Introduction}

Coronary artery disease (CAD) is the leading cause of mortality worldwide (1). Therefore, studies are being conducted in order to elucidate the pathogenesis in detail and to identify new predisposing factors. Currently, a lot of attention is directed towards relationships between vitamin $D$ and CAD. Recent studies have shown that the functions of vitamin D are abundant, including its impact on the development of diseases such as CAD and essential hypertension (2). There is an interplay between vitamin $\mathrm{D}$ and predisposing factors for CAD, diabetes mellitus (3), and obesity (4).

According to studies, vitamin $D$ is involved in the pathogenesis of CAD because cellular recep- 
Tab. 1. Clinical characteristics of the patients with and vitamin D deficiency

\begin{tabular}{|c|c|}
\hline \multicolumn{2}{|l|}{ Characteristics } \\
\hline Total & $n=49$ \\
\hline Age $(25 \% ; 75 \%)$ & $60(54 ; 66)$ \\
\hline Male, n (\%) & $34(69)$ \\
\hline Female, n (\%) & $15(31)$ \\
\hline Obesity, n (\%) & $9(18)$ \\
\hline Smoking, n (\%) & $14(29)$ \\
\hline Alcohol intake, n (\%) & $12(25)$ \\
\hline Physical activity, n (\%) & $17(35)$ \\
\hline Family history, n (\%) & $8(16)$ \\
\hline Essential hypertension, n (\%) & $40(82)$ \\
\hline Max. SBP, mmHg & $180(160 ; 208)$ \\
\hline Max. DBP, mmHg & $112(100 ; 120)$ \\
\hline No CAD history, n (\%) & $23(47)$ \\
\hline Previous MI , n (\%) & $13(27)$ \\
\hline Stable angina, $\mathrm{n}(\%)$ & $21(43)$ \\
\hline Stroke history, n (\%) & $6(12)$ \\
\hline STEMI, n (\%) & $18(37)$ \\
\hline Cholesterol, mmol// & $5,65(4,5 ; 6,4)$ \\
\hline GFR (CKD-EPI), $\mathrm{ml} / \mathrm{min} / 1,73 \mathrm{~m}^{2}$ & $73(56 ; 88)$ \\
\hline AST, IU/L & $65(21 ; 66)$ \\
\hline Troponin +, n (\%) & $31(63)$ \\
\hline
\end{tabular}

Tab. 2. Coronarography results in subgroups

\begin{tabular}{|l|l|}
\hline Characteristics & $\mathrm{N}=49$ \\
\hline Total & $44(90)$ \\
\hline CA occlusion $>50 \%, \mathrm{n}(\%)$ & $26(53)$ \\
\hline CA occlusion $>90 \%, \mathrm{n}(\%)$ & $14(29)$ \\
\hline Total occlusion, $\mathrm{n}(\%)$ & $22(45)$ \\
\hline Multi-vessel disease, $\mathrm{n}(\%)$ &
\end{tabular}

tors to its metabolites are expressed throughout different tissues: smooth muscle cells (5), endothelial cells, cardiomyocytes, as well as inflammatory cells, its proliferation and differentiation control (6). Platelets are also regulated by vitamin D metabolites, which could have an impact on thrombosis (7).

Different regions of the world get different hours of sunlight, which has a direct bearing on vitamin D synthesis in the body (8). CAD mortality and morbidity in many countries increases by $30-50 \%$ in winter compared to summer. Data show a direct relationship between latitude and CAD mortality and morbidity, and an inverse association between altitude and CAD mortality since ultraviolet radiation decreases with latitude but increases with altitude (9).

The objective of our study was to measure serum vitamin $D$ levels in patients with acute coronary syndrome and in the control group.

\section{Methods}

Fifty patients were included into a cross-sectional observational study, all of whom were residents of the Kaliningrad region, Russian Federation, and were urgently admitted to the Kaliningrad Regional Hospital's Department of Cardiology between August and November 2017. Among them, 15 (30\%) were female and 35 (70\%) male; $48 \%$ of the participants (24 patients) were older than 60 years, $46 \%$ (23 patients) were middle-aged (45-60 years), and 6\% (3 patients) were, younger than 45 years. The inclusion criterion was acute coronary syndrome at the time of admission. Exclusion criteria were diabetes mellitus, chronic kidney disease (CKD), autoimmune disorders and malignant tumors. STEMI was diagnosed in 18 (36\%) patients. Twenty-seven (54\%) patients had been previously diagnosed with CAD. Myocardial infarction was diagnosed in 13 (26\%) patients. The mean duration of CAD was 14 months. A first episode of retrosternal pain developed in 23 (46\%) patients. Forty patients (80\%) had essential hypertension, among them 31 (62\%) had stage 3 arterial hypertension. During history taking such factors as obesity, smoking, sedentary lifestyle, alcohol consumption, and family history were assessed.

Also, 22 healthy volunteers with a mean age of $45.32 \pm 5.26$ years were included in our study, 11 (50\%) were male and 11 (50\%) female.

In all participants, the following were assessed: AST, creatinine with GFR (CKD-EPI), and troponin using current laboratory standards. Coronary angiography was performed on General Electric Innova 3100 IQ with «Omnipaque». contrast medium

Serum $25-\mathrm{OH}$ vitamin D was measured with ELISA using microplate photometer (Model 680 Microplate Reader Bio-Rad, USA) and automated microplate washer (Bio-Plex Pro II Microplate Wash Station, USA).

Data analyses were conducted with the aid of StatSoft STATISTICA 7.0. Data were expressed as a percent or mean \pm standard deviation and absolute numbers (percentage) for categorical variables are reported in the present text for continuous and categorical variables. The Mann-Whitney U-test was used to evaluate differences between the two groups for categorical a continous variables, respectively. Moreover, a F-test was used to evaluate the relationship between vitamin $D$ level and coronary artery occlusion grade. A p-value $<0.05$ was deemed statistically significant.

\section{Results}

Between August 2017 and November 2017, 50 patients with ACS and 22 healthy volun- teers were enrolled in our study. The mean age of the participants in the ACS cohort was $59.9 \pm 7.7$ years, with a predominance of males (70\%). Each participant from the ACS cohort underwent history taking and physical examination for detecting CAD risk factors, AST level, creatinine with GFR (CKD - EPI), cholesterol, troponin, serum 25-OH vitamin D and coronary angiography.

Interestingly, for those with ACS, a marked vitamin D deficiency was found in 39 patients (78\%) (serum vitamin D lower than $20 \mathrm{ng} / \mathrm{ml}$ ) and a severe deficiency (lower than $5 \mathrm{ng} / \mathrm{ml}$ ) in 3 patients (6\%). A mildly decreased vitamin D level (21-29 ng/ml) was present in 10 patients (20\%). Only one patient had no vitamin D depletion (> $30 \mathrm{ng} / \mathrm{ml})$.

Table 1 shows the clinical characteristics in the patients of ACS group with vitamin D deficiency.

According to coronary angiography results, almost a half of the patients (45\%) with ACS and vitamin $D$ deficiency had multivessel CAD (Table 2).

In the control group were included subjects without any cardiac disorders. The mean age of patients in the group with acute coronary syndrome and the control group was significantly different ( $p<0.001$ ). In the control group, middle-aged patients prevailed (middle aged -12 young - 10). No elderly patients were enrolled. The youngest patients from the control group were aged 39 years ( 5 of them). The oldest one was 56 years old.

The control group, the median serum vitamin D level was $28.13(24.77 ; 31.74) \mathrm{ng} / \mathrm{ml}$, minimum - 20.67, maximum - $36.14 \mathrm{ng} / \mathrm{ml}$. Vitamin $\mathrm{D}$ deficiency was not observed in the control group, but insufficiency was detected in 14 $(64 \%)$ and normal vitamin D level in 8 persons (36\%), $p<0.001$.

It can be seen from the data in Fig. 1 that the ACS group displayed significantly more vitamin D deficiency than the control group (Fig. 1).

\section{Discussion}

Vitamin D is a steroid hormone, existing as two isoforms, D2 and D3, differing in the side chain. Vitamin D is produced from 7-dehydrocholesterol in the skin after exposure to the B-spectrum ultraviolet light, or after consuming animal or plant foods, containing vitamin D. Vitamin D is 


\section{| ORIGINÁLNÍ PRÁCE}

Pic. 1. Serum vitamin D level comparison in patients with acute coronary syndrome and the control group

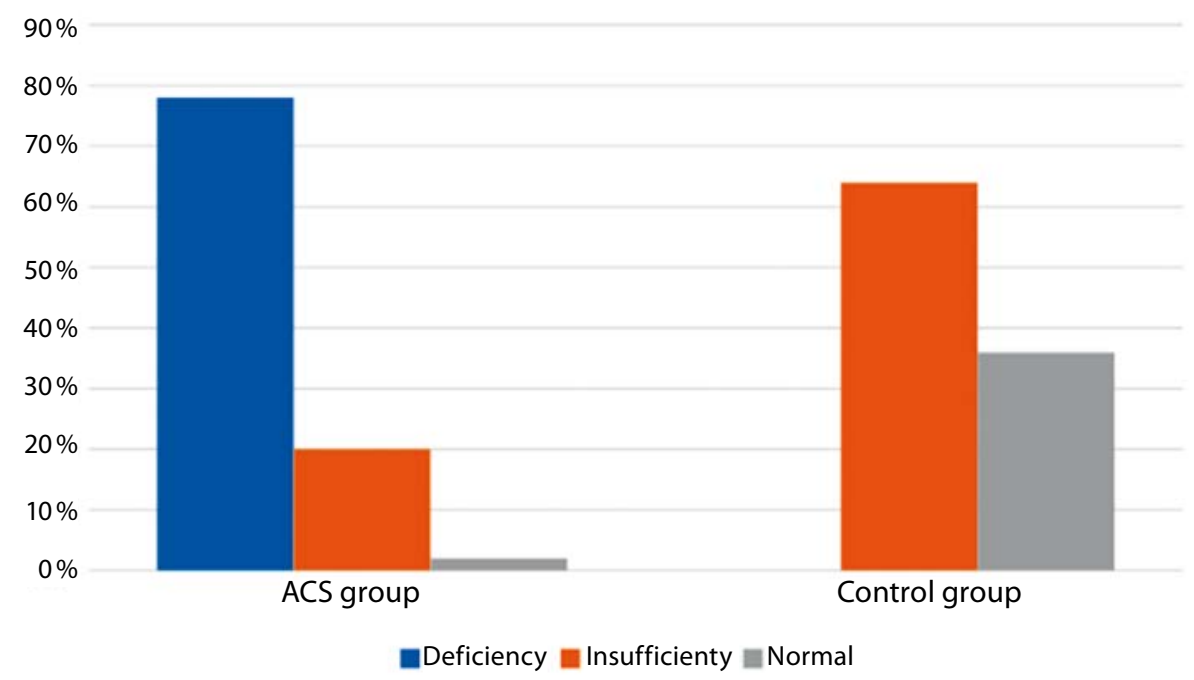

biologically inert, and two hydroxylation reactions are required for effective use. The first hydroxylation reaction occurs in the liver, with the use of vitamin D-25 hydroxylase to form $25(\mathrm{OH})$ vitamin D. The second hydroxylation reaction, with the formation of biologically active forms of vitamin D-1,25 $(\mathrm{OH}) 2 \mathrm{D}$, occurs with the use of $25(\mathrm{OH})$ D-1aOHase (CYP27B1) in almost all tissues. However, serum 1,25 (OH) D level is mainly determined by the activity of renal 1a-hydroxylase, which activity is regulated by the level of calcium, phosphate, parathyroid hormone and FGF-23 (10).

A strong relationship between vitamin $D$ deficiency and CAD has been reported in the literature $(11,12,13,14)$. In the United States, a low level of vitamin $D$ has been linked to important risk factors of leading causes of death (15). Although the current study is based on a small group of patients, the findings suggest the utility of vitamin D deficiency as a predictor of cardiovascular events in patients without concomitant pathological conditions that could contribute to the process of progression of atherosclerosis and could have an effect on the serum vitamin D level: diabetes mellitus, chronic kidney disease, autoimmune diseases, and malignant tumors.

Coronary angiographic findings in our study have revealed that patients with vitamin D deficiency have a high frequency of multi-vessel CAD (45\%). These results are consistent with the findings of other studies, in which a more extensive pattern of angiographic CAD was shown in patients with vitamin D deficiency $(16,17)$.

These findings may help us understand the role of vitamin $\mathrm{D}$ deficiency in patients with
CAD. Still, the issue of vitamin D supplementation has not been addressed properly.

Data from various RCTs and meta-analyses of RCTs on vitamin D supplementation and CAD outcomes are available. A number of studies have found that vitamin D exerts beneficial cardiovascular effects through many pathways, such as reducing RAAS activity, as well as having anti-inflammatory, anti-fibrotic, anti-proliferative, and anti-thrombotic effects (18).

There is a large volume of published meta-analyses describing the role of vitamin D supplementation in CAD outcomes. A recent meta-analysis showed a nonlinear increase in the multivariable-adjusted risk of CVD events at $25(\mathrm{OH}) \mathrm{D}$ levels below $50 \mathrm{nmol} / \mathrm{l}$ but no further decrease in the risk of CVD events at higher levels, i.e. between 50 and $137.5 \mathrm{nmol} / \mathrm{l}$. The risk increased significantly again at levels exceeding $90 \mathrm{nmol} / \mathrm{l}$, indicating an inverse J-shaped association between circulating 25 $(\mathrm{OH}) \mathrm{D}$ levels and the clinical outcome (19). Also, several cohort studies have reported an increased risk of CAD events at a circulating $25(\mathrm{OH})$ D level greater than $100 \mathrm{nmol} / \mathrm{I}$ (20), which can lead to a significant plasma calcium increase.

An Endocrine Society clinical practice guideline recommends treatment of vitamin D-deficient subjects with a 25-OH D level $<19$ $\mathrm{ng} / \mathrm{ml}$ with oral administration of 50,000 IU/ week of either vitamin D2 or D3 for 8 weeks, followed by daily maintenance doses between 1,500 and 2,000 IU with calcium supplementation (21).
The question of whether vitamin D supplementation improves cardiovascular risk factors and reduces subsequent disease remains without a convincing answer. According to the latest meta-analyses vitamin $\mathrm{D}$ supplementation $\geq 4,000 \mathrm{IU} / \mathrm{d}$ and achieved serum $25(\mathrm{OH}) \mathrm{D}$ concentrations $\geq 86 \mathrm{nmol} / \mathrm{I}$ are required to obtain improvements in CAD risk factors (22).

We are looking forward to the results of the randomized, placebo-controlled VITAL study, which will demonstrate whether cholecalciferol supplementation (2,000 IU/day), with or without omega-3 fatty acids, affects the incidence of CAD, stroke, and cancer in $\sim 25,000$ healthy, middle-aged U.S. adults.

According to the Endocrine Society guideline, we would recommend vitamin D supplementation for patients with CAD and vitamin D deficiency (serum $25(\mathrm{OH}) \mathrm{D}<19 \mathrm{ng} / \mathrm{ml}$ ) under serum 25 $(\mathrm{OH}) \mathrm{D}$ control. We would not recommend routine vitamin D supplementation for preventing deficiency since, as mentioned above, a high vitamin D level may increase the risk of CAD events. Further research should be done to investigate the right dosage and duration of vitamin D supplementation. We suppose that for patients with CAD and vitamin $D$ insufficiency and for those at risk of deficiency, the "safest" way to reduce CAD risks is a combination of cholecalciferol supplementation with as much as 2,000 IU/day, casual sunlight exposure and consumption of fatty fish or fish oils.

A further study with more focus on vitamin $D$ supplementation and CAD is therefore warranted.

\section{Conclusion}

We have found in our limited observation that the overwhelming majority of patients with the acute coronary syndrome have vitamin D deficiency, in contrast to the control group individuals with no cardiovascular problems. As the study was conducted during a short period of time, future studies in our region are recommended. Moreover, the issue vitamin D supplementation in preventing CAD requires further investigation.

\section{Conflict of interest}

The authors declare no conflict of interest. The study is financed by the 5 top 100 Russian Academic Excellence Project at the Immanuel Kant Baltic Federal University 
ORIGINÁLNÍ PRÁCE I

\section{REFERENCES}

1. Emelia J. Benjamin, Salim S. Virani,et al. Heart Disease and Stroke Statistics - 2018 Update: A Report From the American Heart Association.Circulation. 2018; 137: e67-e492.

2. 2016 European Guidelines on cardiovascular disease prevention in clinical practice

3. Piepoli, Massimo F, et al. Atherosclerosis, Volume 252, 207-274.

4. Pittas AG, Lau J, Hu FB, Dawson-Hughes B. The role of vitamin $D$ and calcium in type 2 diabetes. A systematic review and metaanalysis. J Clin Endocrinol Metab 2007; 92: 2017-2029.

5. Lamendola CA, Ariel D, Feldman D, Reaven GM. Relations between obesity, insulin resistance, and 25-hydroxyvitamin D. Am J Clin Nutr 2012; 95: 1055-105.

6. Buitrago CG, Arango NS, Boland RL. 1a,25(OH)2D3-dependent modulation of Akt in proliferating and differentiating C2C12 skeletal muscle cells. J Cell Biochem 2012; 113: 1170-1181. 7. Van Etten E, Mathieu C. Immunoregulation by 1,25-dihydroxyvitamin D3: basic concepts. J Steroid Biochem Mol Biol 2005; 97: 93-101.

8. Alshishtawy MM. Vitamin D deficiency: This clandestine endemic disease is veiled no more. Sultan Qaboos Univ Med J. 2012; 12: 140-152.

9. Syal SK, Kapoor A, Bhatia E, Sinha A, Kumar S, Tewari S, et al. Vitamin $D$ deficiency, coronary artery disease, and endothelial dysfunction: Observations from a coronary angiographic study in Indian patients. J Invasive Cardiol. 2012; 24: 385-389. 10. Eva Kassi, Christos Adamopoulos, Efthimia K. Basdra and Athanasios G. Papavassiliou Role of Vitamin D in Atherosclerosis Circulation. 2013; 128: 2517-2531, originally published December 2, 2013

11. Satish Karur, Virupakshappa Veerappa, Manjunath C. Nanjappa Study of vitamin D deficiency prevalence in acute myocardial infarction. Int J Cardiol Heart Vessel. 2014 Jun; 3: 57-59. 12. Pilz S, März W, Wellnitz B, Seelhorst U, Fahrleitner-Pammer A, Dimai HP, Boehm BO, Dobnig H. Association of vitamin D deficiency with heart failure and sudden cardiac death in a large cross-sectional study of patients referred for coronary angiography. J Clin Endocrinol Metab. 2008;.93: 3927-3935. 13. Valentina Milazzo, Monica De Metrio, Nicola Cosentino Giancarlo Marenzi, Elena Tremoli. Vitamin D and acute myocardial infarction. World J Cardiol. Jan 26, 2017; 9(1): 14-20. 14. Naesgaard Patrycja A, León de la Fuente Ricardo A, Nilsen Stein Tore, et al. Suggested Cut-Off Values for Vitamin D as a Risk Marker for Total and Cardiac Death in Patients with Suspected Acute Coronary Syndrome. Front. Cardiovasc Med., 26 February 2016.

15. Forrest KY, Stuhldreher WL. Prevalence and correlates of vitamin D deficiency in US adults. Nutrition Research. 2011; 31(1): 48-54.

16. Serpil Eroğlu, Elif Sade, Emre Özçalık, Gökhan Özyıldız, UğurAbbas Bal, Ersin Doğanözü, Haldun Müderrisoğlu. Asso- ciation between Vitamin D Levels and Presence, Severity of Coronary Artery Disease. Journal of the American College of Cardiology Oct 2013; 62(18 Supplement 2) C119.

17. Dziedzic EA, Gąsior JS, Pawłowski M, Dąbrowski M. Association of Vitamin D Deficiency and Degree of Coronary Artery Disease in Cardiac Patients with Type 2 Diabetes. Journal of Diabetes Research. 2017; 2017: 3929075

18. Mozos I, Marginean O. Links between vitamin D deficiency and Cardiovascular diseases. Biomed Res Int. 2015: 109275 19. Zhang R, Li B, Gao X, Tian R, Pan Y, Jiang Y, Gu H, Wang $Y$, Wang $Y$ and Liu G. Serum 25-hydroxyvitamin D and the risk of cardiovascular disease: dose-response meta - analysis of prospective studies. Am J Clin Nutr 2017; 105: 810-819. 20. Dror Y, Giveon SM, Hoshen M, Feldhamer I, Balicer RD and Feldman BS: Vitamin D levels for preventing acute coronary syndrome and mortality: evidence of a nonlinear association. J Clin Endocrinol Metab 2013; 98(12): 2160-2167.

21. Holick MF, Binkley NC, Bischoff-Ferrari HA, et al. Evaluation, treatment, and prevention of vitamin D deficiency: an Endocrine Society clinical practice guideline. J Clin Endocrinol Metab 2011; 96: 1911-1930

22. Mirhosseini Naghmeh, Rainsbury Jacqueline, Kimball Samantha M. Vitamin D Supplementation, Serum 25(OH)D Concentrations and Cardiovascular Disease Risk Factors: A Systematic Review and Meta-Analysis. Frontiers in Cardiovascular Medicine. 2018; 5: 87 